\title{
Działalność Komisji Kół Krajoznawczych Młodzieży Szkolnej w Polsce okresu międzywojennego
}

\begin{abstract}
Abstrakt
Artykuł dotyczy działalności Komisji Kół Krajoznawczych Młodzieży Szkolnej w Polsce okresu międzywojennego. Ukazuje okoliczności utworzenia Komisji, jej skład oraz regulamin. Przedstawia obszary działalności Komisji, która nadawała jednolity kierunek pracy kołom krajoznawczym młodzieży. Prezentuje rozwój struktur organizacyjnych ruchu krajoznawczego młodzieży. Komisja Kół Krajoznawczych Młodzieży Szkolnej była organem kierującym, opiekującym się i dbającym o rozwój kół krajoznawczych młodzieży w Polsce w okresie międzywojennym.
\end{abstract}

Słowa kluczowe: ruch krajoznawczy młodzieży, komisja kół krajoznawczych młodzieży szkolnej, koła krajoznawcze młodzieży, historia edukacji w Polsce w okresie międzywojennym, organizacje uczniowskie, szkolne koła krajoznawcze.

\section{The Activities of the Committee of School Students' Travel Clubs in Poland in the Interwar Period}

\begin{abstract}
The article concerns the activities of the Committee of School Students' Travel Clubs in Poland in the interwar period. It shows the circumstances of establishing the Committee, its composition and regulations. It presents the areas of activity of the Committee, which gave a unified direction of work to school students' travel clubs. The article also presents the development of the organizational structures of
\end{abstract}

\footnotetext{
* Uniwersytet Szczeciński, Instytut Pedagogiki.

Artykuł otrzymano: 14.02.2020; akceptacja: 26.03.2020.
} 
the students' travel movement. The Committee of School Students' Travel Clubs was the governing body, caring for the development of students' travel clubs in Poland in the interwar period.

Keywords: students' travel movement, Committee of School Students' Travel Clubs, students' travel clubs, history of education in Poland in the interwar period, student organizations, school travel clubs.

\section{Wstęp}

Po odzyskaniu niepodległości z inicjatywy działaczy zaangażowanych w prace Polskiego Towarzystwa Krajoznawczego, rozumiejących znaczenie wychowawcze i kształcące ruchu krajoznawczego, zaczęły powstawać koła krajoznawcze młodzieży. W pierwszej dekadzie lat międzywojennych tworzono je głównie w szkolnictwie średnim, a od drugiej dekady również w szkolnictwie powszechnym (Koła Krajoznawcze Młodzieży Szkolnej... 1934: 9). Ruchem krajoznawczym młodzieży zawiadywała Komisja Kół Krajoznawczych Młodzieży Szkolnej utworzona przez Zarząd Główny Polskiego Towarzystwa Krajoznawczego w 1927 r. Organem prasowym integrującym ruch krajoznawczy młodzieży było czasopismo „Orli Lot” wydawane przez cały okres międzywojenny (Janowski 1933: 6).

Celem artykułu jest przedstawienie działalności Komisji Kół Krajoznawczych Młodzieży Szkolnej w Polsce okresu międzywojennego. Artykuł powstał w oparciu o przeprowadzone badania źródłowe $\mathrm{z}$ wykorzystaniem metodologii historii w zakresie analizy źródeł, metod ustalania faktów, ich porządkowania, klasyfikowania, wyjaśniania, wykrywania związków między nimi i łączenia w syntezę historiograficzną.

Zagadnienie kół krajoznawczych młodzieży w II Rzeczypospolitej było już przedmiotem rozważań nielicznych publikacji. Danuta Koźmian poruszała je, zajmując się poglądami społeczno-pedagogicznymi Aleksandra Kazimierza Patkowskiego (Koźmian 1994: 79-82). Elżbieta Magiera pisała o formalnych aspektach działalności kół krajoznawczych młodzieży w Drugiej Rzeczypospolitej oraz o metodyce szkolnych kół krajoznawczych w okresie międzywojennym (Magiera 2018a: 81-98; 2018b: 121-141). Edyta Wolter zajmowała się wychowaniem do postaw ekologicznych na łamach „Bezpłatnego Dodatku do Miesięcznika Krajoznawczego Orli Lot Poświęconego Ochronie Przyrody“ (Wolter 2015: 221-230), a Urszula Wróblewska przedstawiła cele i organizację Kół Krajoznawczych Młodzieży Szkolnej w okresie międzywojennym (Wróblewska 2017: 183-196). 


\section{Powstanie Komisji Kół Krajoznawczych Młodzieży Szkolnej}

W drugiej połowie lat 20. okresu międzywojennego XX w. Rada Główna Polskiego Towarzystwa Krajoznawczego (PTK), która monitorowała szkolny ruch krajoznawczy i stała się jego głównym organizatorem, mocniej zaangażowała się w jego rozwój. Na posiedzeniu 4 lutego 1927 r. podjęła uchwałę w sprawie zmiany regulaminu Związku Kół Krajoznawczych Młodzieży Szkolnej, w skład którego wchodzili opiekunowie szkolnych kół krajoznawczych i ich członkowie. Decyzje te pozwoliły na utworzenie Komisji Kół Krajoznawczych Młodzieży Szkolnej (dalej Komisja KKMS), powoływanej przez Radę Główną PTK, w skład której wchodzili wszyscy opiekunowie szkolnych kół krajoznawczych (Sprawy organizacyjne. Komisja... 1927: 58-59). Członkami Komisji mogły być również inne osoby zainteresowane szkolnym ruchem krajoznawczym. Po zatwierdzeniu 19 marca 1927 r. regulaminu Komisji jej organizację Rada Główna PTK powierzyła Leopoldowi Węgrzynowiczowi, twórcy i organizatorowi pierwszych kół krajoznawczych w niepodległej Polsce oraz redaktorowi naczelnemu ich organu prasowego „Orlego Lotu”. Komisja mieściła się w Krakowie przy ul. Krowoderskiej 74. W skład zarządu Komisji KKMS oprócz prezesa L. Węgrzynowicza wchodzili: Piotr Galas (zastępca prezesa), Kazimierz Urbański (skarbnik; początkowo skarbnikiem była Maria Medwecka), K. Węgrzynowicz (zastępca skarbnika), Józefa Berggruenówna (zastępca sekretarza; początkowo zastępcą sekretarza była Hanna Sonnoburg-Habenstret), Jadwiga Klimaszewska (zastępca sekretarza) oraz członkowie zarządu: Maria Dobrowolska, Maria Medwecka, Zofia Richterówna i dr Tadeusz Seweryn (Prezydium Komisji... 1927: 123; Pięciolecie... 1932: 69).

\section{Regulamin Komisji Kół Krajoznawczych Młodzieży Szkolnej}

Pełna nazwa nowego organu brzmiała: Komisja Kół Krajoznawczych Młodzieży Szkolnej Rady Głównej PTK (Rok 1927... 1928: 2). Podstawą jej działalności był regulamin zatwierdzony 19 marca 1927 r. i opublikowany w czasopiśmie „Orli Lot” w 1927 i w 1929 r. (Regulamin Komisji Kół Krajoznawczych... 1927: 98-100; Regulamin Komisji Kół Krajoznawczych... 1929a: 136-138). Zgodnie z regulaminem cele Komisji KKMS dotyczyły krzewienia „wśród młodzieży zamiłowania do poznawania kraju, rozwijania ruchu krajoznawczego w Polsce” (Regulamin Komisji Kół Krajoznawczych... 1927: 98-100) i wychowania „przyszłych pionierów ruchu krajoznawczego" (Pięciolecie... 1932: 69). W zakres działań komisji wchodziło: inicjowanie i tworzenie sieci szkolnych kół krajoznawczych, ewidencjonowanie, katalogowanie ich działalności i programu pracy oraz udzielanie wskazówek metodycznych i porad organizacyjnych. Zadaniem Komisji było: koncentrowanie pracy szkolnych kół krajoznawczych wokół organu prasowego „Orli Lot”, który wyznaczał programowo-ideowy kierunek pracy; zbieranie danych i materiałów potwierdzających 
działalność szkolnych kół krajoznawczych; utrzymywanie łączności z krajoznawczymi organizacjami szkolnymi za granicą; urządzanie wycieczek krajoznawczych, których celem było poznanie własnego kraju; organizowanie pomocy wycieczkom za pośrednictwem Poradni Krajoznawczej Rady Głównej PTK; publikowanie materiałów krajoznawczych zebranych przez uczniów na łamach „Orlego Lotu”; organizowanie konkursów, wystaw i innych wydarzeń mających na celu propagowanie szkolnego ruchu krajoznawczego. Realizacja tych zadań wymagała od Komisji KKMS współpracy z istniejącymi towarzystwami krajoznawczymi, turystycznymi i sportowymi oraz Ministerstwem Wyznań Religijnych i Oświecenia Publicznego, które zapewniało Komisji poparcie (Regulamin Komisji Kół Krajoznawczych... 1929b: 1).

Żeby zrealizować określone regulaminem cele i zadania, Komisja KKMS potrzebowała środków finansowych, w skład których wchodziły obowiązkowe składki szkolnych kół krajoznawczych, których wysokość określała Komisja na corocznym walnym zebraniu. Listy szkolnych kół krajoznawczych, które wpłaciły składki, były publikowane na łamach „Orlego Lotu”. Oprócz funduszy pochodzących ze składek Rada Główna PTK zapewniała Komisji określone subwencje finansowe. $\mathrm{Na}$ fundusze składały się również dochody uzyskane z różnych przedsięwzięć podejmowanych z inicjatywy Komisji KKMS, wydawnictw, odczytów i innych działań.

Regulamin Komisji KKMS określał jej wewnętrzną organizację. Przy oddziałach PTK, gdzie istniała większa liczba szkolnych kół krajoznawczych, mogły powstawać sekcje kół krajoznawczych młodzieży szkolnej, w skład których wchodzili opiekunowie kół. Na czele sekcji stał przewodniczący powołany przez zarząd oddziału PTK. Podstawą działalności sekcji był regulamin potwierdzony przez zarząd oddziału PTK oraz przedstawiany Prezydium Komisji KKMS. W miejscowościach, w których funkcjonowało kilka szkolnych kół krajoznawczych, ich opiekunowie tworzyli koło opiekunów. Przewodniczący koła podobnie jak przewodniczący sekcji wchodził w skład zarządu oddziału PTK. Koło opiekunów działało w oparciu o regulamin zatwierdzony przez zarząd oddziału i przesłany do Prezydium Komisji KKMS. Zadaniem koła opiekunów było dbanie o rozwój ruchu krajoznawczego młodzieży i jego jednolity kierunek, organizowanie różnych form aktywności krajoznawczej: wystaw, odczytów, wycieczek i innych przedsięwzięć. W województwie wszyscy opiekunowie kół tworzyli koło okręgowe opiekunów, którego przewodniczący wchodził w skład zarządu okręgu wojewódzkiego PTK (Regulamin Komisji Kół Krajoznawczych... 1929b: 2).

Naczelnym organem rozstrzygającym, kontrolującym i zatwierdzającym postanowienia Komisji była Rada Główna PTK, a organem wykonawczym - Prezydium Komisji. Program, charakter i kierunek pracy ustalało walne zebranie Komisji. Przewodniczącego Komisji powoływała Rada Główna PTK, a walne zebranie wybierało zastępcę przewodniczącego, sekretarza i jego zastępcę oraz skarbnika. Z tego wynika, że prezydium Komisji składało się z pięciu osób, wśród których był 
redaktor „Orlego Lotu”. Regulamin zawierał zapis, że trzej członkowie Komisji muszą mieszkać w miejscu przyjętym za siedzibę Komisji. Walne zebranie Komisji odbywało się raz do roku, a posiedzenia Prezydium Komisji raz w miesiącu. Wnioski sformułowane na walnych zebraniach i posiedzeniach prezydium były referowane na posiedzeniach Rady Głównej PTK (Regulamin Komisji Kół Krajoznawczych... 1927: 20).

\section{Kierunki działalności Komisji Kół Krajoznawczych Młodzieży Szkolnej}

\section{Wytyczne dla pracy kół krajoznawczych młodzieży}

Komisja KKMS czuwała nad jednolitym kierunkiem pracy kół krajoznawczych dzieci i młodzieży. Na łamach „Orlego Lotu” publikowała główne wytyczne pracy kół na dany rok (Główne... 1930: 20). W 1931 r. pisano:

Dziś ogniskujemy na sobie uwagę całej Polski. Władze szkolne pomagając nam, oczekują po nas wyrobienia metod pracy, zbierania materiałów do nauki o Polsce współczesnej, wychowania dzielnych obywateli, znających swój kraj. Społeczeństwo wymaga silnej i zdrowej organizacji, zdolnej do znacznych wysiłków, dającej podwaliny dla siły Państwa Polskiego (Wroku 1931, 1931: 2).

Jednolity kierunek pracy kół krajoznawczych młodzieży osiągano, publikując na łamach „Orlego Lotu” artykuły propagujące regionalizm i krajoznawstwo, ogłaszając konkursy na prace krajoznawcze kół młodzieży, przygotowując i publikując odpowiednie kwestionariusze. Członkowie szkolnych kół krajoznawczych, posługując się kwestionariuszami, prowadzili badania krajoznawcze różnych stron Polski, zbierali materiały geograficzne, krajoznawcze, kulturowe, ludoznawcze i inne, dzięki którym poznawali własny kraj (Informacje... 1929: 129). W pierwszym dziesięcioleciu wydawania „Orlego Lotu” opublikowano 16 kwestionariuszy poświęconych m.in. pisankom, święceniu ziół, przyrodzie, zwyczajom wielkanocnym, sobótkom, opisowi kapliczek, folklorowi, zbieraniu nazw geograficznych, dokumentowaniu głazów narzutowych, oświetleniu mieszkań, monografiom miejscowości i inne. Szkolne koła krajoznawcze były zobowiązane do opracowania jednego kwestionariusza w ciągu roku, uznanego przez Komisję KKMS za obowiązkowy i opublikowanego na łamach „Orlego Lotu”. Wypełnione kwestionariusze należało wysłać do siedziby Prezydium Komisji do Krakowa (Pamiętajmy 1928: 148).

W 1937 r. Komisja KKMS ustaliła regulamin szkolnych kół krajoznawczych, nazywany „Prawa krajoznawcze”, które opublikowano na łamach „Orlego Lotu”. Prawa te zawierały dążenia do poznania ziemi ojczystej i życia kulturalnego, 
gospodarczego, naukowego jej mieszkańców. Wskazywały na potrzebę szanowania przyrody i pomników kultury. Podkreślały potrzebę propagowania zainteresowań krajoznawczych wśród całego społeczeństwa. Nakazywały członkom kół krajoznawczych młodzieży wyrażać zainteresowanie sprawami państwa polskiego, kochać swój kraj i pracować dla jego dobra (Prawa krajoznawcze... 1937: 129).

Od 1937 r. najważniejsze informacje dla kół krajoznawczych młodzieży Komisja KKMS przekazywała za pomocą okólników publikowanych na łamach „Orlego Lotu”. Dla przykładu Okólnik Prezydium Komisji KKMS z 1937 r. skierowany do opiekunów i zarządów kół młodzieży przykazywał kołom zapoznanie się z regulaminem i artykułami dotyczącymi pracy kół krajoznawczych młodzieży publikowanymi na łamach „Orlego Lotu”, a następnie opracowanie własnego planu pracy i przesłanie go do Komisji. W planie pracy na rok szkolny 1937/1938 należało uwzględnić zagadnienia z życia współczesnego, a w szczególności problematykę związaną z życiem wsi, do której zaliczono: bezrobocie i życie rodziny bezrobotnej; reformę rolną; gospodarstwo szałaśnicze; stanowisko kobiety na wsi, ruch gospodyń wiejskich; tradycje warzywnictwa; przemysł ludowy; przemiany kulturalne wsi i inne kwestie (Okólnik Prezydium Komisji... 1937: 123-124). Komisja KKMS ukierunkowywała również potrzeby poznawcze młodych krajoznawców. W 1937 r. zachęcała do organizowania wycieczek szkolnych i wakacyjnych na Pomorze, pisząc, że: „Członków Kół Krajoznawczych Młodzieży oczekuje specjalnie piękna i bogata przeszłością Ziemia Pomorska” (Do Kół Krajoznawczych... 1937: 90). Zachęcała odwiedzić Gdynię, Piaśnicę, Chojnice, Grudziądz, Gniew.

Co roku Komisja KKMS przypominała szkolnym kołom krajoznawczym o ich obowiązkach organizacyjnych. Dla przykładu w latach 1931-1932 należało do nich: kupowanie jednego egzemplarza czasopisma „Orli Lot” na pięciu członków koła; popieranie wydawnictw innych kół; zbieranie wiadomości o życiu i grobach zasłużonych, a zapomnianych Polaków; wypełnianie kwestionariuszy; współpraca z twórcami Słownika Geograficznego; przynależność każdego koła do Ligi Ochrony Przyrody; przesyłanie corocznych sprawozdań z działalności koła; wpłata 1/10 składek członkowskich na konto Komisji w Pocztowej Kasie Oszczędnościowej (Pamiętajcie... 1931: 153, 1932: 143). W 1934 r. Komisja KKMS do najważniejszych obowiązków organizacyjnych zaliczyła: płacenie składek nazywanych dziesięciną, nadsyłanie sprawozdań i opracowanie jednego kwestionariusza (Obowiązki... 1934: 14). W roku 1937 zadaniem kół krajoznawczych młodzieży było: wykonanie opisu kapliczki, przygotowanie się do zjazdu w Pińsku, zebranie funduszy na wysłanie przynajmniej jednego członka na obóz wakacyjny, zapłacenie Komisji dziesięciny i kontynuowanie prenumeraty „Orlego Lotu” (Przypomnienie ... 1937: 162).

Jednolity kierunek pracy nadawały szkolnym kołom krajoznawczym obozy letnie, które organizowała Komisja KKMS. W 1935 r. przygotowano dwa obozy: żeński, który nie doszedł do skutku, i męski dofinansowany przez Ministerstwo WRiOP, kierowany przez Piotra Galasa, który odbył się w terminie 2-23 sierpnia 1935 r. w Jurgowie. Dziennik obozu był opublikowany na łamach „Orlego Lotu” 
(Sprawozdanie prezydium... 1936: 74-75). W 1937 r. Komisja KKMS zorganizowała obóz męski w Pogrzebieniu (pow. rybicki) i obóz żeński w Gibach (pow. suwalski) (Obozy... 1937: 93).

Na łamach „Orlego Lotu” Komisja KKMS publikowała adresy kół krajoznawczych młodzieży działających za granicą, z prośbą o nawiązanie z nimi kontaktów przez szkolne koła krajoznawcze funkcjonujące w szkołach średnich i powszechnych (Skrzynka... 1932: 143). Korespondencja szkolnych kół krajoznawczych, wymiana zdjęć, dorobku, wrażeń była uważana za jedną z cennych metod kształcących i wychowawczych.

\section{Nagrody i konkursy}

Zgodnie z Regulaminem Komisja KKMS przyznawała zbiorowe lub indywidualne nagrody pieniężne lub rzeczowe (książki, fotografie) wyróżniającym się kołom i uczniom (Sprawy organizacyjne. Przyznanie... 1929: 17). Temu celowi służył fundusz nagród, na który składały się subwencje Ministerstwa WRiOP, Ministerstwa Robót Publicznych, Rady Głównej PTK, Oddziałów PTK, Państwowego Komitetu Ochrony Przyrody, Muzeum Etnograficznego w Krakowie, Wydziału Oświecenia w Katowicach, Towarzystwa Ludoznawczego, magistratu Miasta Kraków, dyrekcji szkół średnich i kół krajoznawczych młodzieży (Pięciolecie... 1932: 72). Pomocy finansowej Komisji KKMS udzielały również oddziały PTK, których listy z wysokością wpłat były publikowane na łamach „Orlego Lotu” (Pomoc Oddziałów... 1934: 14). W 1931 r. oprócz nagród pieniężnych i książkowych wprowadzono dyplomy uznania i listy pochwalne (Sprawozdanie Komisji Kół Krajoznawczych... 1931: 46). $\mathrm{Na} ł a m a c h$ „Orlego Lotu” co roku Komisja KKMS ogłaszała konkursy na prace krajoznawcze. Dla przykładu w 1929 r. Prezydium Komisji ogłosiło konkurs dla wszystkich czasopism redagowanych przez uczniów szkół powszechnych i średnich. Nagrodę zapowiedziano tym zespołom uczniowskim, które w ciągu roku szkolnego 1929/1930 wydadzą co najmniej jeden zeszyt własnego czasopisma wypełniony materiałami krajoznawczymi zebranymi przez dzieci i młodzież (Konkurs dla czasopism ... 1929: 139).

\section{Prowadzenie ewidencji kół}

Prezydium Komisji KKMS zbierało dane dotyczące pracy szkolnych kół krajoznawczych, które ze swojej działalności składały roczne sprawozdania. Wyniki tych sprawozdań były wpisywane do indywidualnych kart każdego koła. Dzięki temu prezes Komisji L. Węgrzynowicz był zorientowany w postępie prac każdego koła, a w razie potrzeby mógł udzielać porad i wskazówek. Temu celowi służyła korespondencja, która dochodziła do 3 tys. rocznie wysłanych i otrzymanych listów i różnych przesyłek (Pięciolecie... 1932: 70). Dla przykładu w 1930 r. Prezydium 
Komisji przyjęło 2924 listów, które w głównej mierze dotyczyły spraw szkolnych kół krajoznawczych, ich organizacji, porad, informacji i wskazówek dotyczących pracy kół (Sprawozdanie Komisji Kół Krajoznawczych... 1931: 46).

Usprawnieniu korespondencji służyło utworzenie na łamach „Orlego Lotu” odrębnego działu zatytułowanego Skrzynka na listy, w którym Komisja KKMS publikowała listy od młodych krajoznawców i odpowiadała na nie. W ramach tego działu korespondencję prowadziły również szkolne koła krajoznawcze (Skrzynka na listy. Odpowiedź... 1937: 30).

Każde nowo powstające koło należało zgłosić do Komisji KKMS, podając datę założenia, liczbę członków, liczbę odbytych wycieczek, imprez, kursów oraz dokładny adres szkoły i opiekuna. Zgłoszenia należało przesyłać na ręce przewodniczącego Komisji L. Węgrzynowicza (Informacje... 1929: 129). Celem opracowania zestawienia z działalności szkolnych kół krajoznawczych za pierwsze dziesięciolecie niepodległej Polski Komisja na łamach „Orlego Lotu” zwróciła się do wszystkich kół z prośbą o nadsyłanie sprawozdań zgodnie z załączonym kwestionariuszem, w którym pytano o liczbę członków, odczytów w poszczególnych latach, wypełnionych kwestionariuszy, publikowanych na łamach „Orlego Lotu”, liczbę i miejsce odbytych wycieczek oraz o posiadanie zbiorów krajoznawczych, urządzanie przedstawień, wieczornic, zebrań o charakterze krajoznawczym i ludoznawczym, a także o posiadanie biblioteki krajoznawczej (Sprawy organizacyjne Kół... 1928: 212).

W opublikowanym w 1932 r. na łamach „Orlego Lotu” sprawozdaniu z pięciolecia działalności Komisji KKMS zamieszczono dane dotyczące liczby kół, które przystąpiły do Komisji KKMS: w 1927 r. - 47 szkolnych kół krajoznawczych; w 1928 r. należało 59 kół; w 1929 r. - 96 kół; w 1930 r. - 170 kół; w 1931 r. - 270; w 1932 r. - 366 kół (Pięciolecie... 1932: 70). Systematycznie rosła liczba kół i ich członków. Sprawozdanie Komisji KKMS za 1931 r. wskazywało, że 15 tys. uczniów (270 kół) było zaangażowanych w ruch krajoznawczy młodzieży (Sprawozdanie Komisji Kół Krajoznawczych... 1932: 18-19). Do Komisji KKMS należały: koła krajoznawcze gimnazjów i seminariów nauczycielskich, w których szkolny ruch krajoznawczy zaczął się rozwijać tuż po odzyskaniu niepodległości; sekcje krajoznawcze drużyn harcerskich; koła młodzieży wiejskiej, szkół zawodowych, a od początku lat 30. XX w. - koła szkół powszechnych.

\section{Pieczątki i legitymacje}

W 1928 r. Prezydium Komisji KKMS zatwierdziło model pieczątki i poleciło wprowadzić ją we wszystkich kołach (Prezydium... 1928: 213). W tym samym roku Komisja KKMS opracowała i wydała legitymacje i odznaki dla uczniów zaangażowanych w szkolny ruch krajoznawczy. Na łamach „Orlego Lotu” informowała o zbieraniu przedpłat na odznaki (Sprawy organizacyjne. Do Zarządów... 1928: 114). Pisano o roli i znaczeniu odznaki w następujący sposób: 
Dajemy wam znak, symbol jedności, łączności i wzajemnej miłości wszystkich Kół Krajoznawczych, pracujących dla jednej idei. Niech znak ten nie będzie tylko zewnętrzną ozdobą, lecz spoczywa na piersi prawdziwie czynnego krajoznawcy. Niech będzie wyrazem Waszej ochotnej i pełnej poświęcenia służby dla idei krajoznawczej i gorącej wiary, że skromna praca Wasza jest cegiełką w odbudowie drogiej naszej ojczyzny. (...) Pracując, nie dla sławy, ani wywyższenia, lecz z miłości dla Ojczyzny i wierności dla idei naszej, kroczcie naprzód jednością silni, rozumni szałem, razem młodzi przyjaciele! (Dajemy Wam znak... 1928: 201).

\section{Kursy krajoznawcze dla nauczycieli}

W 1931 r. Prezes Komisji KKMS został poproszony przez Ministerstwo Wyznań Religijnych i Oświecenia Publicznego o przeprowadzenie wykładów na kursach wychowawczych dla dyrektorów szkół i profesorów szkół ogólnokształcących na temat: Koła krajoznawcze młodzieży. Taka decyzja centralnych władz szkolnych wskazała na przywiązywanie wielkiej wagi do szkolnego ruchu krajoznawczego jako czynnika wychowawczego (Rok 1930... 1931: 2).

Na początku lat 30. XX w. Komisja KKMS zajęła się głównie próbą zakładania szkolnych kół krajoznawczych w szkolnictwie powszechnym. L. Węgrzynowicz, prezes Komisji, zorganizował i prowadził w okresie wakacji 4-tygodniowy kurs geograficzno-krajoznawczy dla nauczycieli szkół powszechnych z całej Polski. Dla uczestników kursu wydawano co miesiąc „Biuletyn” poświęcony problematyce krajoznawczo-organizacyjnej. W 1931 r. Komisja KKMS w Krakowie zorganizowała odczyty dla nauczycieli szkół powszechnych, na których mówiono o potrzebie rozwijania krajoznawstwa wśród uczniów (L. Węgrzynowicz) oraz znajomości metodyki pracy krajoznawczej (Stanisława Niemcówna). Opiekunów nowych kół krajoznawczych działających w szkołach powszechnych Krakowa zaproszono na zebranie zapoznawcze, na którym poruszano zasady organizacji krajoznawstwa dla dzieci i młodzieży (Sprawozdanie Komisji Kół Krajoznawczych... 1932: 19). W 1932 r. Komisja KKMS zorganizowała dwa kursy dla nauczycieli szkół powszechnych: jeden w lipcu, w którym uczestniczyły 62 osoby, a drugi w grudniu, w którym wzięło udział 90 nauczycieli. Udział nauczycieli szkół powszechnych w kursach krajoznawczych oznaczał, że idea krajoznawstwa zaczęła rozwijać się w szkolnictwie powszechnym (Rok 1932 ... 1933: 2). W 1933 r. w dniach od 3 do 29 lipca odbył się trzeci kurs metodyczno-krajoznawczy dla nauczycieli szkół powszechnych, zatwierdzony przez Ministerstwo WRiOP i przeprowadzony przez L. Węgrzynowicza. Problematyka kursów była zróżnicowana. W 1931 r. kurs dotyczył przede wszystkim geografii i przyrody, w 1932 r. był poświęcony osadnictwu i stosunkom gospodarczym, a w 1933 r. głównym tematem wykładów była kultura współczesna w sztuce, budownictwie, technice i sporcie (Nauczycielski kurs... 1933: 92). 


\section{Zebrania Komisji Kół Krajoznawczych Młodzieży Szkolnej}

Co roku Komisja KKMS odbywała zebrania, o których pisała w rocznych sprawozdaniach, nielicznie publikowanych na łamach „Orlego Lotu”. Jako przykład może służyć rok 1931, w którym Prezydium Komisji Kół Krajoznawczych Młodzieży Szkolnej odbyło 6 zebrań w Krakowie oraz jedno walne zebranie w Warszawie. Zgodnie ze sprawozdaniem Komisji rok 1930 był poświęcony sprawom organizacyjnym, które przejawiały się w utworzeniu kół opiekunów w Poznaniu, Warszawie i Wilnie, oprócz istniejącego już koła w Krakowie. Powiększono Prezydium Komisji, przyjmując do niego przewodniczących okręgowych kół opiekunów (Sprawozdanie Komisji Kół Krajoznawczych... 1931: 46).

W 1935 r. prezydium Komisji KKMS odbyło 8 posiedzeń, poświęconych opracowaniu kwestionariuszy, programów pracy kół i obozu krajoznawczego, nagrodom dla najlepiej pracujących szkolnych kół krajoznawczych. Oprócz spraw organizacyjnych na posiedzeniach prezydium Komisji wygłaszano referaty dotyczące pracy kół, obozów i wycieczek krajoznawczych. Opracowano dwa kwestionariusze: „Inwentaryzacja cech regionu”, który zatwierdzono jako obowiązkowy dla wszystkich kół krajoznawczych, i drugi kwestionariusz, służący opisowi kapliczek. Z okazji międzynarodowej konferencji poświęconej schroniskom młodzieżowym Komisja KKMS zorganizowała wystawę prac wykonanych przez młodzież w czasie pobytu na obozach krajoznawczych oraz wieczornicę krajoznawczą. Zajęła się powołaniem do życia Szkolnego Muzeum Krajoznawczego (Sprawozdanie Prezydium Komisji... 1936: 74-76). Dzięki współpracy z Ministerstwem WRiOP doszło do wydania okólnika (Okólnik Ministerstwa WRiOP... 1936; Okólnik Ministerstwa WRiOP... 1937), który polecał zakładanie szkolnych kół krajoznawczych i regulował współpracę Komisji KKMS z władzami szkolnymi.

W sprawozdaniu za 1936 r. Komisja KKMS ujęła następujące wykonane zadania: przygotowanie prac szkolnych kół krajoznawczych na wystawę w Dublinie, zorganizowanie zjazdu kół krajoznawczych młodzieży w Krakowie i wystawy prac uczniów w Krakowie, przyznanie nagród kołom wybitnie pracującym, zorganizowanie dwóch obozów i stworzenie Ośrodka Krajoznawczego w Krakowie (Sprawozdanie Komisji KKMS... 1937: 66-72).

\section{Rozwijanie struktur organizacyjnych ruchu krajoznawczego młodzieży}

\section{Okręgowe koła opiekunów}

Komisja KKMS zajmowała się rozwijaniem struktur organizacyjnych ruchu krajoznawczego młodzieży. Wspierała zakładanie okręgowych kół opiekunów, które powstawały w tych województwach lub okręgach szkolnych, na terenie których 
istniało co najmniej 10 szkolnych kół krajoznawczych. Celem okręgowego koła opiekunów było: organizowanie szkolnego ruchu krajoznawczego w obrębie województwa lub okręgu szkolnego; wspieranie wszelkich inicjatyw dzieci i młodzieży, zmierzających do rozwoju szkolnego ruchu krajoznawczego, takich jak: wystawy, wycieczki, zjazdy, biblioteki, zbiory i inne; w porozumieniu z Prezydium Komisji KKMS ustalanie jednolitego kierunku pracy krajoznawczej podejmowanej przez uczniów; sprawowanie kontroli nad działalnością szkolnych kół krajoznawczych oraz współpraca z okręgiem wojewódzkim PTK i Prezydium Komisji KKMS w sprawach administracyjnych, organizacyjnych i finansowych (Sprawy organizacyjne. Regulamin... 1930: 18). W skład okręgowego koła krajoznawczego wchodzili wszyscy opiekunowie kół oraz osoby zainteresowane. Siedzibą zarządu okręgowego koła opiekunów był urząd wojewódzki lub kuratorium okręgu szkolnego. Posiedzenia zarządu obywały się raz na trzy miesiące lub w razie potrzeby. Zarząd składał Komisji KKMS roczne sprawozdania, udzielał wyjaśnień, przedkładał wyniki kontroli szkolnych kół krajoznawczych.

Jako przykład może służyć Okręgowe Koło Opiekunów Kół Krajoznawczych w Bydgoszczy założone w 1931 r., którego celem było: założenie biblioteki; organizowanie pomocy dla młodzieży pozaszkolnej; wygłaszanie referatów; założenie muzeum etnograficznego w Bydgoszczy; przygotowanie się do zjazdów krajoznawczych w Warszawie w 1931 r. i w Bydgoszczy w 1932 r. (Okręgowe Koło Opiekunów... 1932: 14-15). Na łamach „Orlego Lotu” pisano, że na wyróżnienie zasługuje działalność następujących okręgów: Bydgoskiego, Poznańskiego, Wileńskiego i Warszawskiego (Rok 1932... 1933: 2). Okręgowe koła opiekunów dynamiczniej zaczęły się rozwijać w połowie lat 30 . XX w. Oprócz wymienionych okręgów powstały również w Okręgu Krakowskim i Śląskim. 2 grudnia 1934 r. z okazji 15-lecia kół krajoznawczych odbył się Zjazd Okręgowy Opiekunów Kół Krajoznawczych Okręgu Krakowskiego i Śląskiego, któremu towarzyszyła wystawa prac uczniowskich i wieczornica zorganizowana przez młodzież należącą do szkolnych organizacji krajoznawczych (Zjazd Okręgowy... 1934: 127).

Prezydium Komisji KKMS zwoływało ogólnopolskie zjazdy opiekunów kół krajoznawczych. Dla przykładu taki zjazd odbył się 5 kwietnia 1930 r. w Warszawie (Do P.T. Opiekunów... 1930: 46). Na zjeździe wyrażono pogląd, że:

Nauczanie w szkole powszechnej musi być oparte na krajoznawstwie, które ma pierwszorzędne znaczenie na kresach, gdzie trzeba odbudowywać Polskę, odgrzebując w ludzie wspomnienie tego, że tam od wieków była Polska. Narzucać tworzenia kół krajoznawczych nie można z góry, lecz trzeba dążyć do ożywienia ruchu krajoznawczego w szkołach wszelkich typów (Zjazd Opiekunów KKMSz... 1930: 126).

Wśród wniosków rozważano kwestię uzyskania zniżek kolejowych do 75\% przy większych odległościach, zwiększenia liczby domów wycieczkowych i schronisk, zorganizowania czytelni i wypożyczalni krajoznawczej dla wszystkich kół, 
wydania kartek korespondencyjnych, powołania instruktorów wizytujących i udzielających wskazówek poszczególnym szkolnym kołom krajoznawczym, uzyskanie zgody właściwych władz w sprawie przynależności młodzieży szkolnej do Ligi Ochrony Przyrody (Zjazd Opiekunów KKMSz... 1930: 126). Jeśli chodzi o sprawy dotyczące opiekunów szkolnych kół krajoznawczych, to przyjęto wniosek w sprawie zniżki godzin za sprawowanie opieki nad kołem lub uzyskanie wynagrodzenia za pracę.

Kolejny zjazd opiekunów szkolnych kół krajoznawczych i walne zgromadzenie Komisji KKMS odbył się 11 kwietnia 1931 r. w Warszawie w sali Polskiego Towarzystwa Krajoznawczego (Zjazd Opiekunów... 1931: 49). Zjazdowi towarzyszyły uroczystości na ratuszu, przyjęcie przez Prezydenta Rzeczypospolitej, pochód do Belwederu, uroczystości trzeciomajowe, rozmowa z ministrem oświaty i wystawa zjazdowa prac młodzieży (Rok 1932 ... 1933: 2).

\section{Świetlica Krajoznawcza w Krakowie}

Ważnym osiągnięciem Komisji KKMS było utworzenie w 1930 r. świetlicy w Krakowie, której nadano rangę ogólnopolską. Kuratorium Okręgu Szkolnego Krakowskiego wyraziło zgodę na utworzenie w budynku Państwowego Seminarium Nauczycielskiego Męskiego (dyrektor Antoni Mikulski) stałej wystawy prac krajoznawczych w sali, która stała się ośrodkiem życia kół i pracownią krajoznawczą. Miejsce to nazywano świetlicą krajoznawczą, połączoną z czytelnią czasopism krajoznawczych i stałą wystawą prac. W niej odbywały się zebrania prezydium Komisji KKMS, koła opiekunów i inne wydarzenia (Czarnecki 1931: 38). W $1931 \mathrm{r}$. w świetlicy krajoznawczej w Krakowie Komisja KKMS zorganizowała dwie wystawy: jedną poświęconą ochronie przyrody, drugą - pracom krajoznawczym kół okręgu krakowskiego z okazji obchodów 25-lecia Polskiego Towarzystwa Krajoznawczego (Sprawozdanie Komisji Kół Krajoznawczych ... 1931: 46). Warto nadmienić, że Komisja KKMS współorganizowała obchody 25-lecia PTK, na które złożyły się: akademia, otwarcie wystawy prac kół krajoznawczych okręgu krakowskiego, zjazd okręgowy opiekunów szkół i wieczornica ze śpiewami, tańcami, przedstawieniami obrzędów ludowych.

\section{Zrzeszenia Kół Krajoznawczych Młodzieży Szkolnej}

Oprócz miejscowych kół opiekunów, funkcjonujących w większych miastach, zakładano Zrzeszenia Kół Krajoznawczych Młodzieży Szkolnej (KKMS). Przykładowo, Zrzeszenia KKMS w Krakowie i w Wilnie miały własne świetlice krajoznawcze, wyposażone w czytelnię czasopism krajoznawczych, bibliotekę, przezrocza, wystawę zbiorów i prac krajoznawczych (Pięciolecie... 1932: 70). Na początku 1934 r. Komisja KKMS podała do wiadomości regulamin Zrzeszenia KKMS. Celem zrzeszenia była wzajemna pomoc w realizowaniu regulaminu kół krajoznawczych mło- 
dzieży oraz pomoc Komisji „w wypełnianiu jej zadań wychowawczych i krajoznawczych" (Regulamin Zrzeszenia ... 1934: 29). Środkiem prowadzącym do osiągnięcia tych celów było utrzymywanie wspólnej świetlicy oraz organizowanie wspólnych wystaw, odczytów, kursów, wycieczek, wieczorków i innych przedsięwzięć. Fundusze Zrzeszenia KKMS stanowiły wpisowe i składki kół, subwencje i dochody uzyskane z podejmowanych przedsięwzięć i organizowanych imprez. Każde szkolne koło krajoznawcze mogło stać się członkiem zrzeszenia, musiało być tylko przyjęte przez zebranie delegatów kół.

Obowiązkiem kół przyjętych do zrzeszenia było wniesienie wpisowego, opłacanie miesięcznej składki, której wysokość była ustalona przez zebranie delegatów kół oraz dostosowanie się do uchwał zebrania delegatów kół i ustaleń zarządu zrzeszenia. Na czele zrzeszenia stało zebranie delegatów kół, w skład którego wchodziły trzy osoby z każdego koła (prezes lub zastępca i dwóch członków zarządu) (Regulamin Zrzeszenia... 1934: 29). Zebranie delegatów kół pełniło funkcję władzy prawodawczej. Władzą wykonawczą był zarząd zrzeszenia, wybierany raz na rok, w skład którego wchodził prezes, jego zastępca, sekretarz, skarbnik, gospodarz świetlicy. Każde szkolne koło krajoznawcze posiadało jeden głos. Władzę nadzorczą stanowiła komisja rewizyjna zrzeszenia oraz Komisja KKMS w osobach miejscowego koła opiekunów. Uprawnienia zebrania delegatów kół wiązały się z przyjmowaniem kół do zrzeszenia lub ich wykluczaniem, rozdzielaniem tematów wyznaczonych przez Komisję KKMS do opracowania pomiędzy poszczególne koła, wyborem zarządu zrzeszenia i komisji rewizyjnej. Zarząd zrzeszenia kół krajoznawczych młodzieży szkolnej miał obowiązek wykonywania uchwał zebrania delegatów kół, przygotowania wniosków na zebranie delegatów kół, opiekowania się świetlicą, zbierania składek i dbania o fundusze zrzeszenia, przygotowywania raz do roku sprawozdań z działalności zrzeszenia przedkładanych zebraniu delegatów kół (Regulamin Zrzeszenia... 1934: 30).

Sprawozdania z działalności zrzeszeń zamieszczano na łamach „Orlego Lotu”. Przykładem było Zrzeszenie Kół Krajoznawczych Młodzieży Szkolnej w Bydgoszczy, które powstało 14 grudnia 1931 r. na zebraniu kół krajoznawczych bydgoskich szkół średnich (Jednodniówka... 1933: 6). Dzięki staraniom Komisji KKMS zostało utworzone Zrzeszenie Kół Krajoznawczych Młodzieży Szkolnej w Krakowie, które otrzymało wspomnianą wcześniej świetlicę, wyposażoną w czytelnię, otwartą 1 października 1933 r., czynną trzy razy w tygodniu w godzinach od 16.00 do 19.00 . W świetlicy toczyło się życie zrzeszenia, ponieważ tam odbywały się zebrania, kursy, próby, odczyty (Sprawozdanie Zrzeszenia Kół... 1934: 124).

\section{Zjazdy kół krajoznawczych młodzieży}

Co roku Komisja KKMS organizowała zjazdy kół krajoznawczych, które odbyły się w Krakowie (1927), Wilnie (1928), Poznaniu (1929), Krzemieńcu (1930), Warszawie (1932), Bydgoszczy (1933), Krakowie (1936), Pińsku (1937), Lwowie (1938) 
(Staszewski 1968: 155-158; Pięciolecie... 1932: 72). Ogólnopolskie zjazdy Kół Krajoznawczych Młodzieży Szkolnej były miejscem spotkań dzieci i młodzieży zaangażowanych w szkolny ruch krajoznawczy oraz ich opiekunów, organizatorów, ideologów krajoznawstwa, przedstawicieli władz oświatowych i innych osób wyrażających swoje zainteresowanie rozwijaniem krajoznawstwa w szkołach. Zjazdy były miejscem wymiany myśli i doświadczeń krajoznawczych oraz prezentacji prac i osiągnięć młodych krajoznawców. Uczestnicy zjazdów brali udział w obradach, odczytach, zwiedzaniu miasta, w którym odbywał się zjazd, oraz w wieczornicy krajoznawczej, na której członkowie kół krajoznawczych przedstawiali tańce i śpiewy ludowe ze swoich okolic, obrzędy i sceny z życia ludu (zaloty, wesele, dożynki, inne) (Informacje... 1929: 192). Zjazdy dawały „wgląd w pracę innych kół, stają się przez to bodźcem i zachętą do dalszej, intensywniejszej pracy" (Pięciolecie... 1932: 72).

W związku ze zjazdami delegatów kół krajoznawczych Komisja KKMS zachęcała do zakładania krajoznawczych kas oszczędności. Zaoszczędzone środki finansowe miały być przeznaczone na opłacenie wyjazdów zjazdowych i udział aktywnych członków kół w letnich obozach (Krajoznawcze kasy... 1934: 13).

\section{Ośrodek Krajoznawczy i Szkolne Muzeum Krajoznawcze}

W 1931 r. Komisja KKMS zainicjowała utworzenie Nauczycielskiego Ogniska Krajoznawczego w Krakowie, które integrując środowisko nauczycieli zaangażowanych w rozwój ruchu krajoznawczego dzieci i młodzieży, udzielało porad metodycznych, organizowało kursy, wycieczki i pomoc nauczycielom zaangażowanym w pracę krajoznawczą z młodzieżą (Janowski 1933: 6-7).

W 1935 r. Komisja KKMS zapoczątkowała działalność Szkolnego Muzeum Krajoznawczego w Krakowie, które gromadziło uczniowskie prace. Za pośrednictwem „Orlego Lotu” zwracała się do opiekunów kół krajoznawczych młodzieży o nadsyłanie prac, fotografii, rysunków, modeli, kronik, plakatów dokumentujących działalność szkolnego ruchu krajoznawczego. Celem muzeum było dokumentowanie „pracy nauczyciela i ucznia nad poznaniem kraju ojczystego” (Szkolne Muzeum... 1935: 136). Zanim jednak Komisja utworzyła muzeum, powołała do życia nowe ogniwo w pracy organizacyjnej międzywojennego szkolnego ruchu krajoznawczego, którym był Ośrodek Krajoznawczy w Krakowie, mieszczący się przy ul. Bronisława Biernackiego 25, otwarty codziennie w godzinach od 16.00 do 19.00 . Ośrodek Krajoznawczy traktowano jako zaczątek Szkolnego Muzeum Krajoznawczego (Sprawozdanie Komisji KKMS... 1937: 68-69). Jego celem było:

gromadzić prace krajoznawcze młodzieży, prowadzić dokładną ich ewidencję tak, aby udostępnić je naukowcom, wychowawcom i młodzieży, gromadzić środki pomocnicze jak wydawnictwa, modele, przezrocza, potrzebne do nauczania krajoznawstwa w szkole i do prowadzenia pracy w kołach młodzieży (Ośrodek Krajoznawczy... 1937: 2). 
W strukturze Ośrodka Krajoznawczego wyodrębniono dwa działy. Jeden obejmował zbiory i wystawę prac młodzieży, drugi - bibliotekę, czytelnię, zbiory ilustracji, przezroczy i inne. W 1937 r. z nadesłanych prac przygotowywano wystawę międzynarodową w Tokio. Ośrodkiem opiekowali się młodzi krajoznawcy z Uniwersytetu Jagiellońskiego, którzy porządkowali i inwentaryzowali prace uczniów. Utworzenie Ośrodka poparło Ministerstwo WRiOP oraz Kuratorium Okręgu Szkolnego Krakowskiego. Poparcie centralnych i terenowych władz szkolnych było wyrazem docenienia szkolnego ruchu krajoznawczego. Komisja KKMS sugerowała, żeby podobne ośrodki, ogniskujące ruch krajoznawczy młodzieży, powołać w innych miastach Polski. Postulowała, by zarządy ośrodków służyły pomocą w pracach wychowawczych i krajoznawczych, by nawiązały współpracę ze wszystkimi szkołami średnimi i powszechnymi, z nauczycielami zaangażowanymi w szkolny ruch krajoznawczy, z młodzieżą pozaszkolną. Na zakończenie informacji o ośrodkach krajoznawczych Komisja KKMS wystosowała następujący apel:

A więc do pracy! Starajmy się, aby Imię Polski jaśniało na pierwszym miejscu kulturalnego świata i by Koła Krajoznawcze młodzieży stały się pionierami pracy krajoznawczej, prace ich chlubą i dowodem wysokiego poziomu kulturalnego młodzieży polskiej! (Ośrodek Krajoznawczy... 1937: 3).

\section{Zakończenie}

Powołanie Komisji Kół Krajoznawczych Młodzieży Szkolnej przez Radę Główną PTK w 1927 r. było wyrazem zjednoczenia szkolnego ruchu krajoznawczego. Dzięki temu, że w skład Komisji wchodzili wszyscy opiekunowie uczniowskich kół krajoznawczych oraz że Komisja była organem Zarządu Głównego PTK, zapewniono stałą łączność szkolnego ruchu krajoznawczego z Polskim Towarzystwem Krajoznawczym. Przez osobę L. Węgrzynowicza, który był redaktorem naczelnym „Orlego Lotu” organu prasowego kół krajoznawczych młodzieży szkolnej i jednocześnie pełnił funkcję przewodniczącego Komisji KKMS, koła krajoznawcze młodzieży miały zapewniony jednolity kierunek działalności, który był ogłaszany na łamach „Orlego Lotu”. Komisja KKMS działała w oparciu o regulamin, który określał jej cele, zadania, wewnętrzną strukturę, członków, fundusze i organy.

Komisja KKMS przywiązywała dużą wagę do stosunku młodzieży do krajoznawstwa, który miał przejawiać się w jej aktywnym zaangażowaniu w pracę na rzecz poznawania Polski i regionu. Zmierzała do tego, by młodzież nie tylko poznawała wkład minionych pokoleń w dzieje państwa i narodu, ale by również dawała wkład z siebie i swojej pracy krajoznawczej. Aktywność członków szkolnych kół krajoznawczych była propagowana przez Komisję na dorocznych zjazdach, na których młodzież prezentowała swój dorobek, oraz na łamach „Orlego Lotu”, na których szkolne koła krajoznawcze publikowały własne opracowania, a także 
w codziennej pracy, której przyświecało hasło „Poznać, żeby ukochać”. Komisja KKMS rozumiała znaczenie wychowawcze i kształcące krajoznawstwa. Ponadto: „Po odzyskaniu niepodległości kształtowanie postaw opartych na miłości do Ojczyzny oraz rozbudzanie zainteresowań poznawczych własnym krajem sprzyjały procesom integracyjnym ziem polskich i ich mieszkańców" (Magiera 2018a: 93-94).

Należy podkreślić, że Komisja KKMS opracowała cztery regulaminy: kół młodzieży, okręgowych opiekunów szkolnych kół krajoznawczych, zjazdów kół krajoznawczych młodzieży oraz regulamin zrzeszenia kół krajoznawczych młodzieży. Zajmowała się rejestrowaniem kół krajoznawczych młodzieży i ich sprawozdawczością. Dbała o przygotowanie nauczycieli do pełnienia funkcji opiekuna szkolnych kół krajoznawczych. Organizowała konkursy krajoznawcze i przydzielała nagrody. Zajmowała się organizacją wypoczynku letniego młodzieży. Wydała legitymacje i odznaki dla członków kół młodzieży. Dbała o rozwój struktur organizacyjnych ruchu krajoznawczego młodzieży, przejawiający się w zakładaniu okręgowych kół opiekunów, zrzeszeń kół krajoznawczych młodzieży, urządzaniu zjazdów kół krajoznawczych młodzieży. Przyczyniła się do założenia Ośrodka Krajoznawczego, Szkolnego Muzeum Krajoznawczego oraz Nauczycielskiego Ogniska Krajoznawczego w Krakowie. Instytucje te pełniły funkcję integrującą ruch krajoznawczy młodzieży. Na zakończenie trzeba podkreślić wielkie zaangażowanie członków Komisji w rozwój szkolnego ruchu krajoznawczego w II Rzeczypospolitej, który nie tylko wzbogacił ofertę edukacyjną międzywojennej Polski, ale realizując cele wychowawcze i kształcące przyczynił się do wychowania rzeszy samodzielnych, aktywnych i twórczych obywateli państwa oraz pozbawionych uprzedzeń i stereotypów, szanujących inne regiony i ich kultury członków wielonarodowego społeczeństwa.

\section{Bibliografia}

Czarnecki J. R. (1931) W naszej świetlicy w Krakowie „ „Orli Lot”, nr 3, s. 38.

Dajemy Wam znak! (1928), „Orli Lot”, nr 10, s. 201.

Do Kół Krajoznawczych Młodzieży Polskiego Towarzystwa Krajoznawczego (1937), „Orli Lot”, nr 6, s. 90.

Do P.T. Opiekunów Kół Krajoznawczych Młodzieży Szkolnej (1930), „Orli Lot”, nr 3, s. 46.

Główne wytyczne pracy Kół na r. 1930 (1930), „Orli Lot”, nr 1, s. 20.

Informacje o prawach i obowiq̨zkach kół krajoznawczych młodzieży szkolnej organizowanych przez Polskie Towarzystwo Krajoznawcze (1929), „Orli Lot”, nr 8, s. 129.

Janowski A. (1933) Koła Krajoznawcze Młodzieży, Kraków, Drukarnia „Orbis”. 
Jednodniówka krajoznawcza z okazji Zjazdu Kół Krajoznawczych Młodzieży Szkolnej w Bydgoszczy dnia 16 i 17 czerwca 1933 r. (1933) Bydgoszcz, Wydawca Komitet Wykonawczy Zjazdu, s. 6.

Koła Krajoznawcze Młodzieży Szkolnej. Idea - Organizacja - Historia - Pieśni, (1934) Kraków, Nakład Komisji Kół Krajoznawczych Młodzieży Szkolnej Rady Głównej Polskiego Towarzystwa Krajoznawczego.

Konkurs dla czasopism młodzieży szkolnej (1929), „Orli Lot”, nr 6, s. 139.

Koźmian D., Poglądy społeczno-pedagogiczne Aleksandra Kazimierza Patkowskiego (1890-1942) (1994), Szczecin Wydawnictwo Naukowe Uniwersytetu Szczecińskiego.

Krajoznawcze kasy oszczędności (1934), „Orli Lot”, nr 1, s. 13.

Magiera E. (2018a) Metodyka pracy szkolnych kół krajoznawczych w Polsce okresu międzywojennego, „Biuletyn Historii Wychowania”, nr 38, s. 81-98.

Magiera E. (2018b) The formal aspects of the activities conducted by School Students' Sightseeing Clubs in the Second Republic of Poland: 1918-1939, "The Journal of History and Education", No. 3/4, s. 121-141.

Nauczycielski kurs krajoznawczy (1933), „Orli Lot”, nr 6, s. 92.

Obowiązki organizacyjne (1934), „Orli Lot”, nr 1, s. 14.

Obozy instruktorskie (1937), „Orli Lot”, nr 6, s. 93.

Okólnik Ministerstwa WRiOP (nr 66) z dnia 8 lipca 1937 r. w sprawie ruchu krajoznawczego (1937), Dz.U. MWRiOP, nr 8, s. 336.

Okólnik Ministerstwa WRiOP z dnia 22 października 1935 w sprawie Kół Krajoznawczych Młodzieży Szkolnej (1936), Dziennik Urzędowy Kuratorium Okręgu Szkolnego Brzeskiego, nr 2, s. 34 .

Okólnik Prezydium Komisji Kół Krajoznawczych Młodzieży Szkolnej do opiekunów i zarzq̨dów kół młodzieży (1937), „Orli Lot”, nr 8, s. 123-124.

Okręgowe Koło Opiekunów Kół Krajoznawczych w Bydgoszczy (1932), „Orli Lot”, nr 1, s. $14-15$.

Ośrodek Krajoznawczy (1937), „Orli Lot”, nr 1, s. 2-3.

Pamiętajcie o obowiq̨zkach organizacyjnych (1931), „Orli Lot”, nr 8/9, s. 152.

Pamiętajcie o obowiązkach organizacyjnych (1932), „Orli Lot”, nr 9, s. 143. 
Pamiętajmy! (1928), „Orli Lot”, nr 7, s. 148.

Pięciolecie Komisji Kół Krajoznawczych Młodzieży Szkolnej Rady Głównej PTK (od 5/VI 1927 do 30/III 1932 r.) (1932), „Orli Lot”, nr 5, s. 69-72.

Pomoc Oddziałów PTK dla Komisji KKMS (1934), „Orli Lot”, nr 1, s. 14.

Prawa krajoznawcze Młodzieży Krajoznawczej PTK (1937), „Orli Lot”, nr 9/10, s. 129.

Prezydium Komisji Kół Krajoznawczych Młodzieży (1927), „Orli Lot”, nr 6, s. 123.

Prezydium Kół Krajoznawczych Młodzieży (1928), „Orli Lot”, nr 10, s. 213.

Przypomnienie (1937), „Orli Lot”, nr 3/4, s. 62.

Regulamin Komisji Kół Krajoznawczych Młodzieży Szkolnej Rady Głównej Polskiego Towarzystwa Krajoznawczego (1927), „Orli Lot”, nr 5, s. 98-100.

Regulamin Komisji Kół Krajoznawczych Młodzieży Szkolnej Rady Głównej Polskiego Towarzystwa Krajoznawczego (1929a), „Orli Lot”, nr 6, s. 136-138.

Regulamin Komisji Kół Krajoznawczych Młodzieży Szkolnej Rady Głównej Polskiego Towarzystwa Krajoznawczego (1929b), Kraków, Drukarnia „Orbis”.

Regulamin Zrzeszenia (1934), „Orli Lot”, nr 2, s. 29-30.

Rok 1927 (1928), „Orli Lot”, nr 1, s. 2.

Rok 1930 (1931), „Orli Lot”, nr 1, s. 2.

Rok 1932 (1933), „Orli Lot”, nr 1, s. 2.

Skrzynka na listy (1932), „Orli Lot”, nr 9, s. 143.

Skrzynka na listy Odpowiedź kołom pytającym: co robić? (1937), „Orli Lot”, nr 2, s. 30.

Sprawozdanie Komisji KKMS za rok 1936 (1937), „Orli Lot”, nr 5, s. 66-72.

Sprawozdanie Komisji Kół Krajoznawczych Młodzieży Szkolnej od 1 stycznia do 31 grudnia 1931 r. (1932), „Orli Lot”, nr 2, s. 18-19.

Sprawozdanie Komisji Kół Krajoznawczych za czas od 1 I do 31 XII 1930 r. (1931), „Orli Lot", nr 3, s. 46.

Sprawozdanie prezydium Komisji KKMS za rok 1935 (1936), „Orli Lot”, nr 5, s. 74-76. 
Sprawozdanie Zrzeszenia Kół Krajoznawczych Młodzieży w Krakowie za rok 1933/4 (1934), „Orli Lot”, nr 8, s. 124.

Sprawy organizacyjne Kół (1928), „Orli Lot”, nr 10, s. 212.

Sprawy organizacyjne. Do Zarządów Kół Krajoznawczych Młodzieży Szkolnej (1928), "Orli Lot”, nr 5, s. 114.

Sprawy organizacyjne. Komisja Kół Krajoznawczych Młodzieży Szkolne Rady Głównej Polskiego Towarzystwa Krajoznawczego (1927), „Orli Lot”, nr 3, s. 58-59.

Sprawy organizacyjne. Przyznanie nagród (1929), „Orli Lot”, nr 1, s. 17.

Sprawy organizacyjne. Regulamin Okręgowych Kół Opiekunów Kół Krajoznawczych Młodzieży Szkolnej Polskiego Towarzystwa Krajoznawczego (1930), „Orli Lot”, nr 1, s. 18.

Staszewski K., Koła Krajoznawcze Młodzieży Szkolnej PTK (1968), „Ziemia”, nr 2, s. $155-158$.

Szkolne Muzeum Krajoznawcze w Krakowie (1935), „Orli Lot”, nr 7, s. 136.

W roku 1931 (1931), „Orli Lot”, nr 1, s. 2.

Wolter E., Wychowanie do postaw ekologicznych na łamach „Bezpłatnego Dodatku do Miesięcznika Krajoznawczego Orli Lot Poświęconego Ochronie Przyrody Wydawanego Nakładem Państwowej Rady Ochrony Przyrody“ (2015), „Kwartalnik Historii Nauki i Techniki", nr 1, s. 221-230.

Wróblewska U. (2017) Cele i organizacja Kół Krajoznawczych Młodzieży Szkolnej $w$ okresie międzywojennym w: Turystyka $w$ edukacji historycznej i obywatelskiej, M. Ausz, J. Bugajska-Więcławska, A. Stępnik, D. Szewczuk (red.), Lublin, Wydawnictwo UMCS, s. 183-196.

Zjazd Okręgowy w Krakowie (1934), „Orli Lot”, nr 8, s. 127.

Zjazd Opiekunów KKMSz w Warszawie dnia 5 kwietnia 1930 r. (1930), „Orli Lot”, nr 7, s. 126.

Zjazd Opiekunów (1931), „Orli Lot”, nr 3, s. 49. 